\title{
Niels Albertsen
}

\section{Retfærdiggørelse, ideologi, kritik}

Denne artikel har tre formål. For det første er det hensigten at udrede forbindelserne mellem begreberne retfærdiggørelse, ideologi og kritik, som de foreligger hos Luc Boltanski og Ève Chiapello i Le Nouvel Esprit du capitalisme (1999) (NEC i det følgende) og denne bogs forudsætninger. For det andet skal forholdet mellem kritisk sociologi og kritiksociologi afklares. Boltanski markerer sig i 1980-90erne med en tese om, at sociologien om de sociale aktørers kritiske kompetencer bør erstatte en sociologi, som selv vil være kritisk. I NEC vender imidlertid en idé om kritisk sociologi tilbage. Her skal de to tilgange integreres, som det hedder i forordet til den engelske udgave af NEC (Boltanski \& Chiapello 2005:xii). Hvordan hænger dette sammen? For det tredje skal Boltanski og Chiapellos (B\&C i det følgende) begrebs- og teoridannelse præciseres gennem konfrontation med dels en marxistisk forståelse af ideologi og kritik, dels aktør-netværksteorien i Bruno Latours udgave, ifølge hvilken kritisk sociologi er noget af det værste og mest skadelige, der er hændt samfundsvidenskaben. Et kort blik på den anerkendelsesteoretiske fornyelse af kritisk teori (Axel Honneth) bidrager til præciseringen.

Søgeord: Retfærdiggørelse, ideologi, kritik, Boltanski, Latour, Žižek. 


\section{Fra kritik til pragmatik: den pragmatiske vending i fransk sociologi}

I midten af 1980erne vender nogle franske sociologer ryggen til den "mistænksomhedens" sociologi, som spørger efter forhold og kræfter, der "ligger bag" den sociale interaktion (Luhmann 2000). I stedet advokerer de for en pragmatisk sociologi, som beskriver og ekspliciterer foreliggende social interaktion ved at "følge aktørerne selv", som det hedder med et slagord (Latour 2005: 12). Over for den kritiske sociologi, som hævder nødvendigheden af et epistemologisk brud med agenters og institutioners forudforståelser og fordomme for at trænge frem til determinerende hierarkier af strukturer og kræfter, hævdes en "irreduktionisme", som tager aktørernes selvforståelse alvorligt og redegør for den mangfoldighed af handlingsformer og tingsligt medierede situationer, de agerer i (Latour 1984; Bénatouil 1999: 383).

Hovedfigurer i den pragmatiske vending er dels Bruno Latour og Michel Callon, hvis indsats har fundet kanoniseret form som aktør-netværksteorien (ANT) (Latour 2005: 9), dels de to elever af Pierre Bourdieu, Luc Boltanski og Laurent Thévenot, som har bestræbt sig på at begrebsliggøre forskellige pragmatiske regimer for tingsmedieret social interaktion. Boltanski har således sondret mellem fire forskellige regimer ud fra om de er 1) fredelige eller konfliktuelle og 2) reguleret af ligheds- eller ækvivalensprincipper eller ej. Det giver fire regimer: retfærdiggørelsens, rigtighedens (justesse), kærlighedens og voldens regimer (Boltanski 1990: 110-124, jf. fig. 1). Thévenot sondrer mellem tre forskellige "engagementsregimer": retfærdiggørelsens regime, hvor der står offentlig strid om det fælles bedste, familiaritetens regime, hvor engagementet gælder de nære og kendte omgivelser, og planens regime, hvor engagementet gælder projektion ind i fremtiden og de hertil krævede funktionelle nødvendigheder (Thévenot 2006: 8-11; Thévenot 2007b: 414-418). Det følgende fokuserer på retfærdiggørelsens regime.

Figur 1.

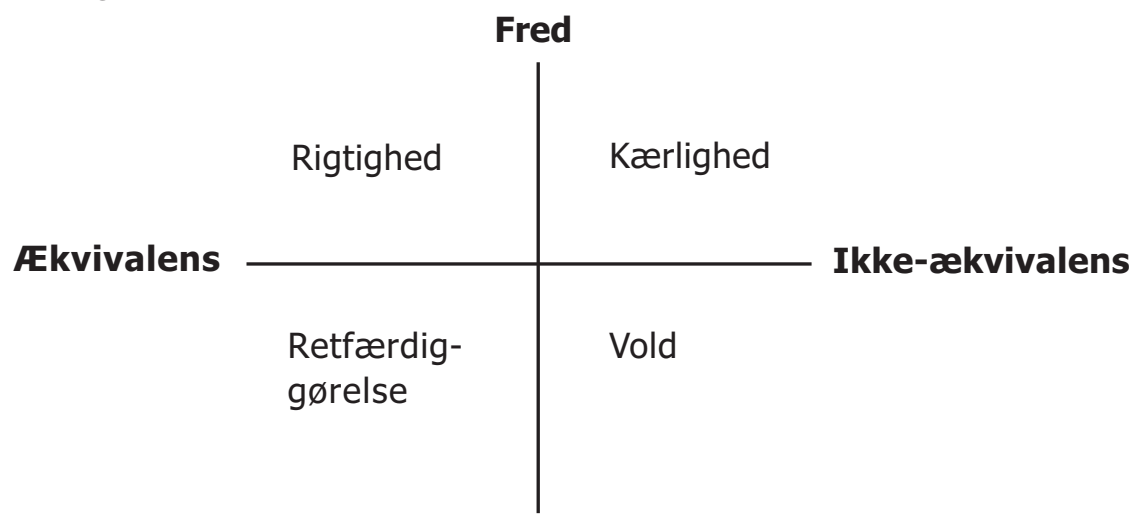

Konflikt 


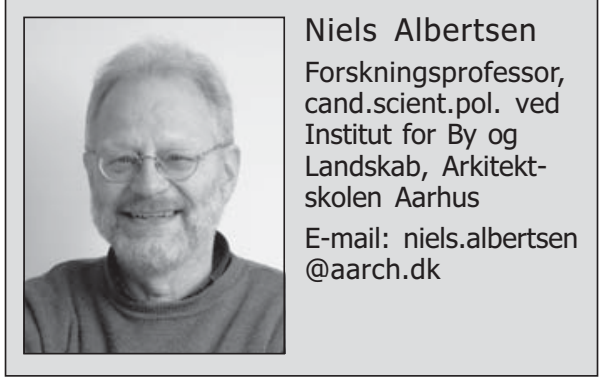

\section{Retfærdiggørelsens regimer ${ }^{1}$}

I De la justification. Les économies de la grandeur fra 1991 (DJ i det følgende) undersøger Boltanski og Thévenot (B\&T i det følgende) retfærdiggørelse som tingsformidlet social praksis, der drejer sig om at finde legitime løsninger på offentlige retfærdighedskonflikter. Legitimiteten undersøges som sådan og ikke som legitimering af bagvedliggende interesser og kræfter (B\&T 1991: 53-57).

Ifølge $B \& T$ besidder almindelige mennesker i moderne, komplekse og differentierede samfund en pluralistisk retfærdiggørelseskompetence, en "metafysisk evne", en "sans for det retfærdige", som kan aktiveres i konflikter om retfærdighed. Det "metafysiske" går på, at konfliktsituationen kan bedømmes ud fra en pluralitet af generelle principper, som transcenderer den konkrete situation (B\&T 2000: 213, 215, 208-212). Disse principper artikuleres på systematisk vis af den politiske filosofi, hvilket er baggrunden for, at B\&T på fransk betegner retfærdiggørelsesprincipperne med begrebet "Cité" (Boltanski 2006: 24). Der henvises også til den græske bystat og dens retfærdige (politiske) indretning (Boltanski 1990: 98, 106). I det følgende anvendes "regime" [cité], hvorimod "retfærdiggørelsesregime" [régime de justification] bruges som samlebegreb for retfærdiggørelsens pragmatiske regime til forskel fra andre pragmatiske regimer.

Regimerne har visse fællestræk, som B\&T sammenfatter i en "modèle de la Cité". Det væsentlige ved denne regimemodel er, at alle "borgere" på den ene side besidder en frelles humanitet, hvilket på den anden side ikke udelukker retfærdige forskelle mellem mennesker. Dog kræver normen om fxlles værdighed, at sådanne forskelle ikke fæstnes permanent på enkeltpersoner. Alle har i princippet lige adgang til de højeste goder, men der skal gøres en indsats, investeres, for at nå dem. Denne anstrengelse anerkendes af alle, da godet er et frlles gode og anstrengelsen således til fælles bedste. Det er altså ikke uretfærdigt, at nogen tæller mere end andre, for "størrelse" ("grandeur") er til det fælles bedste, dvs. også til bedste for de "små" (B\&T 1991: 96-100; Boltanski 2008: 18-19).

Regimerne har modellen til fælles, men de har forskellige overordnede principper, forskellige "grammatikker" (B\&T 1991: 26). I DJ redegøres for seks sådanne regimer: inspirationsregimet, domesticitetsregimet, opinionsregimet, borgerregimet, markedsregimet og det industrielle regime. Disse seks regimer udtømmer imidler- 
tid ikke det moderne samfunds retfærdiggørelsesregime. Nye samfundsmæssige betingelser skaber grobund for nye regimer. Claudette Lafaye og Laurent Thévenot har således argumenteret for opkomsten af et grønt eller økologisk regime (Lafaye \& Thévenot 1993: 512-514) og Boltanski og Chiapello har argumenteret for, at et projektregime (cité par projet) har udviklet sig i samspil med kapitalismens fleksibilisering og globalisering og opkomsten af en "netværksverden" (B\&C 1999: 158, 64). Det generelle princip er her aktivitet af en hvilken som helst art, der skaber eller integrerer en række projekter - jo mere forskelligartede jo bedre. Man skal være mobil, men handle til det frlles bedste, dvs. engagere sig i andre, skabe tillid, være tolerant, respektere forskelle og distribuere information, så alle, store som små i netværket, kan fastholde og forøge deres anvendelighed ("employability") i nye projekter (ibid.: 16567, 181-82). ${ }^{2}$ Projektregimet opstår med kapitalismens forandringer siden 1980erne, men rækker i stigende grad ind i det private og bio-politiske område (Boltanski 2004: 140-144; Boltanski 2006: 29-41).

\section{Retfærdiggørelse, test, kritik}

Regimerne har deres "basis" i samfundsudviklingen. Der fandtes markeder, købmænd og profitorienterede argumenter før Adam Smith skrev Wealth of Nations, hvilket var grundlaget for at Smith kunne artikulere et retfærdiggørelsesprincip for et markedsregime (B\&T 1991: 94-96). Som metafysisk grund for moderne menneskers praktiske sans for retfærdighed er regimerne historisk og samfundsmæssigt skabte. De er i tid, rum og samfundsmæssige institutioner legemliggjorte principper (B\&C 1999: 624-628). Moderne menneskers transcenderende evne er en historisk og samfundsmæssigt skabt og virkende evne (Albertsen 2005: 79).

Transcendensens dennesidighed bliver endnu tydeligere, når vi ser på retfærdiggørelsens konfliktsituation. Her foregår en legitimitetstest, en efterprøvning af et retfærdighedsspørgsmål, hvor det i selve "prøvelsen" skal vise sig, hvilke entiteter der retmæssigt hører hjemme i striden, og hvad de dur til. Som det hedder med Spinoza: vi ved ikke, hvad noget er i stand til, før det er prøvet af (B\&C 1999: 73-74, 681-682). Entiteterne omfatter både menneskelige og ikke-menneskelige aktører. Boltanski, Thévenot og Chiapello deler her aktør-netværksteoriens opfattelse, at mennesker grundlæggende - med Latours formulering - deler socialiteten med tingene (B\&T 1991: 35; Latour 1996: 235). I stridens situation engageres både mennesker og ting (B\&T 1991: 163). Der foretages en "realitetstest", som ikke kun hviler på sproglig kommunikation og argumentation, men støtter sig til og inddrager de for stridens art adækvate eller "kvalificerede" ting (B\&T 2002: 7; 1991: 31, 165, Boltanski 2008: 17-18). Et regime, betragtet som enheden af transcendente principper og en kohærent verden af relevante kvalificerede entiteter, udgør samlet set en "fælles verden" (B\&T 1991: 165).

Stridigheder i retfærdiggørelsens verdener kan antage tre principielt for- 
skellige former. De kan dreje sig om, hvorvidt et regime er anvendt korrekt. Kritik kan her "afsløre", at efterprøvningen ikke er god nok som legitimitetstest, da andre kræfter blander sig for meget. Kritikkens mål er da at korrigere og forbedre testen gennem renselse. Retfærdiggørelse, legitimitet og kritik går i denne korrigerende kritik hånd $\mathrm{i}$ hånd (B\&C 1999: 76; B\&T 1991: 271-274).

Til forskel fra denne reformistiske kritik drejer striden i den radikale kritiks tilfælde sig om, hvilken retfærdiggørelsesverden, der er den rette (B\&C 1999: 77). Kritik vil her hævde, at et andet regime end det påkaldte bør gælde i den konkrete situation. Her står altså kritik ud fra forskellige regimer over for hinanden i den samme situation (B\&T 1991: 276). En tredje form for strid mellem forskellige regimer gælder "uklare situationer", hvor entiteter fra forskellige verdener byder sig til for engagement i den situationelle efterprøvning (B\&T 1991: 278). Her kan striden opløses i et kompromis, hvor entiteter fra forskellige verdener danner en sammensat situation (assemblage), uden at denne reguleres ved rekurs til én enkelt verden (B\&T 1991: 337).

$D J$ indeholder et omfattende system til kategorisering af retfærdiggørelsens verdener og en gennemgang af hver enkelt af disse (B\&T 1991: 177-181; 200262). ${ }^{3}$ Dette, såvel som en omfattende krydsgennemgang af de gensidige muligheder for kritik og kompromis, skal jeg lade ligge her (B\&T 1991: 266-407; Albertsen 2002: 55-56). Det afgørende er sammenhængen i det pragmatiske retfærdiggørelsesregime mellem retfærdiggørelse, kritik og situationel efterprøvning. Kritik og retfærdiggørelse er her intimt forbundne: kritikken støtter sig til regimerne, hvad enten den er korrektiv eller radikal. Ingen kritik uden retfærdiggørelse. Det er budskabet, i hvert fald inden for rammerne af $D J$.

\section{Transcendens, immanens og styrke: kategorisering og forskydning}

I NEC undersøges andre reaktioner på kritik end dem, som er solidt plantet på retfærdiggørelsens grund. Således kan den korrigerende kritik besvares på anden vis end ved at forbedre legitimitetstesten. Man kan vige uden om for at undgå omkostningerne ved forbedringen, søge at mindske testens betydning, søge nye veje gennem mangfoldige små og knapt synlige, forandrende tiltag. Lykkes det, så har man afuæbnet kritikken gennem en serie af mikroforskydninger, som har forandret den omstridte situation (B\&C 1999: 77-79). Legitimitetstesten er forvandlet til ren "styrkeprøve", "styrken" har sat "størrelsen", legitimitetens "grandeur", ud af spillet (ibid.: 74). Styrkeprøve og legitimitetstest er således ikke skarpt adskilte fra hinanden, men kontinuerte med hinanden (ibid.: 75), idet legitimitetstesten også er en styrkeprøve, blot underlagt retfærdiggørelsens restriktioner (Boltanski 2008: 27). Kritik kan altså afsløre uvedkommende magt- og styrkeforhold, mens forskydning kan afvæbne afsløringen.

Retfærdiggørelsens transcendens udfordres således af forskydningens immanens. Forskydningen styres ikke af overordnede generelle principper, 
den bevæger sig ikke "opad" i generalitet, men skubber horisontalt konfliktsituationen et andet sted hen (B\&C 1999: 62, 74, 409-411). På forskydningens "immanensplan" (Deleuze) gælder kun styrkeforskelle (ibid.: 551, 226, 160). Men fra immanensplanet kan et nyt "transcendensplan" (min betegnelse) rejse sig gennem det B\&C kalder kategorisering, dvs. udarbejdelse af et nyt værdisæt som kan begrunde, hvad det fælles bedste er i de nye sammenhænge (ibid: 627, 405-406).

\section{Ideologi, legitimitet og legitimering}

$B \& C$ søger i NEC at forene to forskellige synsvinkler på kritik: kritik som strid på legitimitetens grund og kritik som afsløring af magt og styrkeforhold. På lignende vis søger de også at forene to forskellige ideologiopfattelser: en kulturel og en kritisk. Kulturelt set udgør ideologi et socialt repræsentationssystem, en "helhed af fælles opfattelser, indskrevet i institutionerne, inddraget $\mathrm{i}$ handlinger og således forankrede i virkeligheden" (Chiapello 2003: 155; B\&C 1999: 35). Kritisk set fordrejer, tilslører, skjuler ideologi andre sociale forhold, især udbytning og undertrykkelse. Ideologi er "falsk bevidsthed" frembragt af netop de sociale forhold, den er falsk bevidsthed om. Ideologikritik består da i at retvende fordrejningen gennem oplysning (Chiapello 2003: 156; Bjerre \& Laustsen 2006: 30). Over for ideologiens integrative og identitetsbevarende funktion står således dens fordrejningsfunktion (Chiapello 2003: 159). Legitimeringsbegrebet formidler imidlertid mellem de to funktioner, idet ideologi samtidig kan sikre en magtudøvelses legitimitet og kaste et legitimerende dække over den magtudøvelse, som er illegitim (ibid.: 161). Ideologikritik kan da på legitimitetens grundlag afsløre den dominans, som dækker sig blot legitimerende bag selv samme legitimitet.

\section{Kapitalismens ånd som ideologi}

B\&C henter (selvfølgelig) begrebet om kapitalismens ånd fra Max Weber (1972), som hævder, at den moderne kapitalisme (forstået som et økonomisk system kendetegnet ved profitjagt gennem fredelige midler, kapitalakkumulation og rationel organisering af formelt fri arbejdskraft) ikke kan opstå historisk ud fra egne kræfter. Kapitalismens økonomiske system forudsætter en ny praktisk-rationel livsførelse, en "etos", som må skaffes udefra. Denne "etos" er kapitalismens "ånd" og den leveres af calvinismen, ikke mindst gennem dens håndbøger i puritansk, kaldsstyret livsførelse (Albertsen 2005: 72). B\&C fastholder nu, modsat Weber, at behovet for ekstern støtte ikke kun gælder kapitalismens opkomst, men også dens videre reproduktion og udvikling. Som økonomisk akkumulationssystem, der låser kapitalister fast i en abstrakt og uendelig akkumulationsproces og berøver arbejderne frugten af deres arbejde og muligheden for et aktivt liv uden underkastelse, er kapitalismen absurd og amoralsk. Den behøver fortsat en "ånd", en ideologi, som kan levere gode grunde til at engagere sig i systemet (B\&C 1999: 41-42).

I sine forskellige historiske former har kapitalismens ånd tre dimensioner 
til fælles. Den skal påpege det stimulerende ved at involvere sig med systemet, redegøre for hvorfor det er sikkert at gøre det og hvorfor, det er retfardigt. Det stimulerende vedrører sædvanligvis muligheder for frigørelse, sikkerheden muligheden for at opretholde livet for familie og børn og retfærdigheden det kapitalistiske systems bidrag til det fælles bedste (ibid.: 53-54). I sidste henseende støtter den kapitalistiske ideologi sig til forskellige kompromisser mellem retfærdiggørelsens regimer. Siden 1800-tallet har kapitalismens ånd taget tre forskellige former. Den første, som jeg vil kalde iværksætterånden, fokuserede på den entreprenante borger, den borgerlige familie og paternalistisk velgørenhed. Den støttede sig til et kompromis mellem det domestiske og det markedsmæssige regime. Kapitalismens anden ånd, som jeg vil kalde organisationsånden, fokuserede på den store tayloristisk-fordistiske virksomhed, på magtudøvelsen i organisationen, på karriereplanlægning, velfærd og meritokrati. Den støttede sig til et kompromis mellem det industrielle og det borgerlige regime. Kapitalismens nye ånd, som jeg vil kalde projektånden, fokuserer på kreativitet og horisontale relationer, "employability" og projektregimet (ibid.: 54-57, 64).

Kapitalistisk ideologi fungerer således socialt integrerende (stimulans og sikkerhed) og legitimitetsskabende (retfærdiggørelse). Den skaber et fælles tilhørsforhold til samme økonomiske system og retfærdiggør dets måde at fungere på, herunder de "stores" forrang for de "små". Men ideologien giver også mulighed for at afsløre legitimeringen af de "stærkes" forrang for de "svage", at de store er for stærke og de små for svage (Chiapello 2003: 165-67). Således muliggør "et og samme begrebsapparat [...], at man skifter fra ideologiens integrative funktion til dens fordrejningsfunktion" (ibid.: 169).

\section{Kritikkens to niveauer: indignation og refleksion}

Ligesom ideologibegrebet sætter retfærdiggørelsen ind i en større sammenhæng, således opererer B\&C også med en bredere ramme om kritikbegrebet. Kritik forudsætter, at der er forskel mellem "en ønskelig tingenes tilstand og en reel tingenes tilstand" (B\&C 1999: 69) af et sådant omfang, at forskellen bliver "kilde til indignation". Men der er lang vej fra indignationen til den kritik, som artikuleres i termer af det fælles bedste. Hertil behøver kritikken "teoretisk støtte" og "argumenterende retorik". Den udtrykte kritik omfatter således to niveauer: et "primært niveau", som er et "følelsernes domæne", der "altid kan flamme op i nye situationer", og et "sekundært niveau", som er "refleksivt, teoretisk og argumenterende". Det sekundære niveau gør kritikken i stand til "ideologisk kamp", men kritikken kan, som ovenfor nævnt, også afvæbnes ved at immanente forskydninger fjerner kritikkens forbindelse til en retfærdiggørelsesverden. Afvæbning af kritik gælder således det sekundære niveau, som jeg vil kalde kritikkens transcendensplan. Det primære niveau, som jeg vil kalde kritikkens immanensplan, kan forblive uberørt af transcendensens sammenbrud. Selv når "de kritiske kræfter synes totalt opløste, kan evnen til at indigneres forblive intakt" (ibid.: 81-82). 


\section{Kapitalismekritikkens to hovedformer: kunstnerisk og social}

Siden 1700-tallet har kapitalismen været udsat for stærk antikapitalistisk kritik, som ifølge B\&C har taget form af henholdsvis kunstnerisk og social kritik. Den kunstneriske kritik, kunstneres og bohemers kritik, gælder primært affortryllelse, inautenticitet og undertrykkelse. Kapitalismen kritiseres for at skabe meningsløshed, for at undergrave sansen for det smukke og storslåede gennem al tings standardisering og varegørelse og for at undergrave (den kunstneriske) frihed gennem undertrykkelse af menneskers arbejde. Den sociale kritik, som har været båret af den socialistiske og marxistiske arbejderbevægelse, har primært fokuseret på egoismen, på særinteressernes dominans i det borgerlige samfund og de folkelige klassers voksende elendighed i et samfund præget af vækst i rigdom. De to kritikker kan ikke uden videre forenes. Således kan den kunstneriske kritik, som gerne friholder æstetikken fra etisk omklamring, fra den sociale kritiks etiske synspunkt kritiseres for netop immoralitet og kunstneregoisme (ibid.: 82-84).

\section{Social kritik, retfærdiggørelse og udbytning}

Spørger man nu til kapitalismekritikkens teoretiske grundlag og til dens "normative støttepunkter"(ibid.: 69), så overrasker det, at B\&C ikke direkte knytter an til retfærdiggørelsens regimer. Det fortjener nærmere undersøgelse. Vedrørende den sociale kritik er især B\&Cs udbytningsteori for netværkskapitalismen interessant. Ifølge denne teori kan "de store" i projektregimet, dvs. de mobile, hævdes at udbytte "de små", de immobile, hvis to betingelser er opfyldt. For det første skal de immobiles aktivitet (sekretæren på kontoret) være nødvendig for de mobile. De immobile skal eksempelvis bidrage til at sikre, at de mobiles sociale kapital, som altid er konkret og personbundet, ikke fortabes netop på grund af mobiliteten. I netværkets knudepunkt holder de immobile sammen på netværket (ibid.: 446-448). "Udbytning" finder så for det andet sted, hvis de immobiles bidrag til den samlede værdiforøgelse ikke aflønnes på en sådan måde, at fordelingen mellem de mobile og de immobile "kan hævdes at være rimelig" (ibid.: 448, min kursivering).

Lægger vi nu regimemodellen til grund for forståelsen af dette udbytningsbegreb, så må der sondres mellem legitim ulighed og illegitim udbytning. De immobile må indrømme de mobile deres storhed i det omfang, den er proportionel med de mobiles investering, og i øvrigt fungerer til det fælles bedste. Hvad, der rækker ud over dette, er urimelig udbytning. På denne måde kan regimemodellen begrunde en socialkritisk udbytningsteori. Dette synes også at være B\&Cs opfattelse, hvilket implicit fremgår af deres sondring mellem udbytning i svag og stærk forstand. Udbytning i stærk forstand rammer selve den menneskelige værdighed. Kritikken heraf støtter sig på "værdighedsprincippet", idet udbytningen i én verden kan blive så omfattende, så "intens, at den rammer selve vitaliteten", hvorved de ramte personer forhindres i at manife- 
stere, hvad de evner, også i alle andre verdener. Dette strider mod princippet om ikke at fæstne størrelsesforhold en gang for alle på enkeltpersoner. Til forskel herfra gælder udbytning i svag forstand alene urimelige fordelingsforhold, "krænkelsen af retfærdighedssansen" - målt i forhold til ét regime, må man gå ud fra (ibid.: 450).

Regimemodellen kan imidlertid kritiseres for ikke at være radikal nok (Bidet 2002). Ifølge modellen kan de "store" fortjene, meritere, deres fordele, men modellen mangler et kriterium for at måle rimeligheden af de fordele, meriteringen giver. I marxistisk udbytningsteori kan arbejdsværditeorien levere et sådant ækvivalensprincip, og uden et sådant grundlag kan et radikalt begreb om menneskers lighed træde til. På baggrund heraf vil merittens legitimitet kunne "afsløres" som uretfærdig legitimering af styrkeforhold (ibid.: 216-217).

Retfærdigvis skal det siges, at B\&C gør opmærksom på, at den sociale kapitalismekritik har støttet sig normativt til de lighedsværdier, som historisk har været forbundet med borgerskabets opkomst og kapitalismens udvikling, og at kapitalismekritikken generelt er tæt forbundet med moderniteten, demokratiet og oplysningen (B\&C 1999: 83, 588). For så vidt anerkender også B\&C, at kapitalismekritikken bygger på det, Bidet kalder en "grande cité", et overgribende regime, som retter sig mod helheden af samfundsmæssige relationer, og som bygger på lighedsprincippet (Bidet 2002: 222-223). At dette også gemmer på en kritik af selve regimemodellen, synes B\&C derimod ikke at være opmærksomme på.

\section{Kunstnerisk kapitalismekritik hinsides retfærdiggørelsen}

Den kunstneriske kritik retter sig særskilt mod kapitalismens tendens til at standardisere og varegøre alt: hverdagslivets genstande, kunstens værker og menneskene selv (B\&C 1999: 84). Denne kritik minder meget om den kritik, som fra inspirationens verden kan rettes mod markedets verden og den industrielle verden (B\&T 1991: 294-296). Men B\&C refererer ikke hertil. Det skyldes formentlig, at den kunstneriske kritik ikke grunder sig på retfærdiggørelse. Generelt har venstreorienteret kapitalismekritik ikke følt sig forpligtet til at "afsløre den etiske basis for sin indignation". Det må tværtimod fremtiden vise. Når kritikken har virket, når betingelserne for et nyt menneskes opståen er realiseret, så vil det vise sig, hvad den etiske basis var (Boltanski 2002: 4). Denne betragtning gælder ikke mindst den kunstneriske kritik, som med basis i den revolutionære romantiks dyrkelse af geniet retter blikket mod en fremtidig humanitet (ibid.: 6-7). Den kunstneriske kritik af undertrykkelsen baserer sig ifølge $B \& C$ på oplysningens og borgerlighedens frihedsværdier. Det moderne frigørelsesprojekt kritiseres for ikke at frigøre menneskers potentialer for autonomi, selvorganisation og kreativitet. De underlægges i stedet instrumentalismens jernbur (B\&C 1999: 83, 86). Heller ikke her peges der eksplicit på retfærdiggørelsens regimer. 
Den normative basis for den kunstneriske kritik findes altså ikke i retfærdiggørelsesregimet. Dette bekræftes, hvis vi betragter den Marxske kapitalismekritik i lyset af de to kritikker. Hos Marx funderes den sociale kritik i udbytningsteorien i Kapitalen. Svaret herpå er socialismens "til enhver efter indsats". Den kunstneriske kritik knytter sig derimod til ungdomsskrifternes fremmedgørelseskritik og forestillingen om kommunismen som virkeliggørelsen af menneskets mangfoldigt aktive artsvæsen, hvor alle yder efter evne og nyder efter behov hinsides enhver fiksering i en arbejdsdeling (B\&C 1999: 677; Boltanski 1990: 204-212). Boltanski har med rette påpeget at denne "cité communiste" ikke drejer sig om retfærdigørelse (Boltanski 1990: 211). I kommunismen er "hver enkelts frie udvikling [...] betingelsen for alles frie udvikling" (Marx \& Engels 1971: 47). Frihedens rige gælder "den absolutte udarbejdelse af menneskets skabende anlæg". Mennesket forsøger ikke at forblive, hvad det allerede er, men befinder sig i "tilblivelsens absolutte bevægelse" (Marx 1974: 387). Ingen bedømmes "store" eller "små" efter retfærdiggørelsens alen. Alle udfolder aktivt deres potentialer i forhold til hinanden, viser i fortsat handling nye, ukendte sider af, hvad deres evner formår og nyder andres efter behov (jf. Boltanski 1990: 212). Den kommunistiske "cité" er således slet ikke en "cité", ikke et regime, men selve kritikken af enhvert regime. Dette er den "normative orientering" i Marxs værk. Heraf hans ironiske distance til den borgerlige retfærdighed (ibid.: 210).

Frigørelse hinsides retfærdiggørelsen har Bruno Karsenti fat i på anden vis. Han påpeger det "opfindsomme, uforudsigelige, kreative" ved enhver styrkeprøve. Et "irreduktibelt overskud af kræfter" gør sig således også gældende, hvis prøven gælder størrelsesforhold. Dette overskud presser grænserne for, hvad retfærdiggørelsestesten gælder (Karsenti 2000: 159). Her er, vil jeg mene, en særskilt etik på spil: en spinozistisk-marxistisk-nietzscheansk-deleuziansk etik, som ikke bevæger sig på retfærdiggørelsens transcendensplan, men søger at forene indignation og tilblivelse på immanensens plan. Her finder eksempelvis Michael Hardt og Antonio Negri $(2000,2004)$ det revolutionære potentiale i Imperiets "multitude". De overser dog, at netværkskapitalismen i det mindste delvist har indfanget den aktivistiske tilblivelses kraft i retfærdiggørelsesregimets rammer, nemlig i projektregimet, som jeg derfor har foreslået tager paradoksal form af en "cité spinoziste" (Albertsen 2005: 81).

\section{Kritik og kapitalistisk dynamik}

Boltanski karakteriserer NEC som en "sammenhængende fortælling" om kapitalismens udvikling de sidste 30 år, hvis "scenografi" bygger på tre "aktanter" $\mathrm{i}$ indbyrdes dynamik: kapitalismens ånd, kapitalismen, og kapitalismekritikken (Boltanski 2002: 7; Blondeau \& Sevin 2008: 55). Lad os se lidt nærmere på, hvordan $B \& C$ redegør for denne dynamik.

Det kapitalistiske økonomiske system kendetegnes på den ene side af en konkurrencedrevet egendynamik, som fremkalder teknologisk innovation, nye 
former for arbejdsorganisation, nye produkter og tjenester, fortsat "kreativ destruktion" og fortsatte forskydninger i den kapitalistiske akkumulations substantielle indhold (B\&C 1999: 88-90). På den anden side er kapitalismekritikken også en afgørende kraft i kapitalismens udvikling - så afgørende, at kapitalismen ikke kan overleve og udvikle sig uden. B\&C ræsonnerer, så vidt jeg kan se, på følgende måde: Kapitalismen behøver som amoralsk og absurd system en kapitalistisk ånd, som må tilvejebringes fra eksterne ressourcer. Men systemet kan ikke af sig selv, gennem en slags funktionalistisk eller systemisk tilpasningslogik, integrere forhåndenværende kulturelle ressourcer i de sociale omgivelser i en kapitalistisk ånd. Kapitalismen skal tværtimod presses til at legitimere sig, hvilket kapitalismekritikken sørger for. Kapitalismen tvinges af sine fjender til at svare på kritik, hvilket den så gør ved delvis at indoptage kritikken i kapitalismens ånd og transformere sig derefter. "Kapitalismen behøver sine fjender" for at opnå den robusthed, systemet historisk har udvist (ibid.: 69).

B\&C hævder nu endvidere, at uden kapitalismekritik ville der ikke være behov for kapitalismens ånd (ibid.: 81). Dette undrer, fordi de hermed synes at se bort fra den kapitalistiske ånds funktionelle nødvendighed. Også uden kapitalismekritik ville den absurde kapitalisme vel behøve eksterne ressourcer for at sikre engagement og tilslutning. Men velvilligt læst synes sammenhængen at være, at kapitalismen som absurd og amoralsk akkumulationssystem "nødvendigvis" fremkalder kritik (ibid.: 581). Det ligger så at sige i kapitalismens begreb, at den avler kritik af abstrakt, umættelig akkumulation og hele eksistensens usikkerhed. Kapitalisme og kapitalismekritik er således internt forbundne begreber. Uden kapitalismekritik altså rigtignok ingen kapitalismens ånd, men dermed heller ingen kapitalisme. Den ville ikke kunne fungere. Den ville bryde sammen, tendere mod "selvdestruktion" af mangel på legitimitet, engagement, ideologi, ånd (ibid.: 583, 613-616). Kapitalismen behøver både ånd og kritik, og den fremkalder ånden indirekte ved at fremkalde kritik.

\section{Kritiksociologi, kritisk sociologi og kritisk kritiksociologi}

Den pragmatiske vending indebærer et skift fra kritisk sociologi til en "sociologi om kritikken" - en kritiksociologi. Denne beskriver og analyserer, hvordan kritik finder sted i vore "kritiske samfund", hvor aktørerne selv agerer kritisk. Kritiksociologien fremfører ikke selv kritik, tilbagefører ikke aktørernes fortolkninger til "sociale strukturer", men lader sig i stedet føre af "de stabile former", der viser sig i aktørernes redegørelser. Forskeren skaber overblik over og ekspliciterer disse former og rekonstruerer de kognitive kompetencer, aktørerne bruger ved retfærdiggørelse og kritik (Boltanski 1990: 54-57, 60-62).

Denne "udfoldelse" af meningen med aktørernes handlinger kan, som Boltanski påpeger med henvisning til Paul Ricœur, betragtes som en "mistænksomhedens hermeneutik", idet den afdækker noget mere i redegørelserne, 
end de umiddelbart udtrykker. Men afsløringsmåden er anderledes end i den kritiske sociologi. Det er en "rekonstruktionens hermeneutik", som udfolder diskursernes og handlingernes mening, og som forstås af de fortolkede aktører. I stedet for "at modsige det, der siges", får den "det, der siges, til at brillere" (Boltanski et al. 2006: 50-51).

Kritiksociologien er virksom i NEC ved at eksplicitere de regimer, der indgår i kapitalismens ånd, ved at rekonstruere deres indbyrdes kritik og ved at udrede, hvordan de i kapitalismens ånd fungerer som basis for kritik af kapitalistiske excesser. Aktørernes internalisering af kapitalistisk ånd pålægger kapitalakkumulationen restriktioner, hvorved den kapitalistiske ånd leverer såvel retfærdiggørelse og kritik af kapitalismen (B\&C 1999: 66).

Fokuseringen på forholdet mellem legitimitet og styrke gør ikke i sig selv kritiksociologien til kritisk sociologi. Vi står fortsat med en kritiksociologi, som påviser, at der i det "kritiske samfund" forefindes og aktiveres regimer, der kan begrunde kritik af "styrkeforhold" på basis af legitime "størrelsesforhold". Magten og styrken er ikke underliggende og skjulte kræfter, der afsløres af en kritisk sociologi, men handlingsmåder, som ligger på samme horisontale immanensplan som indignationen og, kunne man tilføje, den frigørende tilblivelse. Styrkens immanensplan er ikke skjult "bag" retfærdiggørelsens transcendensplan i anden forstand end, at transcendensplanet ikke i sig selv henleder opmærksomheden på styrkebetingede forskydninger. For så vidt og uden sammenligning i øvrigt kan man med Luhmann sige, at det, der ligger bag, alene er "det, der ikke iagttages ved iagttagelsen", men som kan iagttages ved en anden iagttagelse (Luhmann 2000: 22).

Heller ikke redegørelsen for den kunstneriske og sociale kritik, hvor kritik har andre baser end regimerne, bringer os fra en kritiksociologi til en kritisk sociologi. Der er intet skjult ved den kunstneriske og sociale kritik, som kritiksociologien bringer frem i lyset. Der er intet bagvedliggende, som åbenbares til aktørernes overraskelse.

Alligevel taler B\&C om NEC som en bestræbelse på at kombinere og integrere kritisk sociologi med kritiksociologi (2005: xii), og en så indgående kender af Boltanskis, Thévenots og Chiapellos arbejder som Philippe Corcuff har ligefrem karakteriseret NEC som "kritisk sociologi" (Corcuff 2004: 118). Der gemmer sig altså en kritisk sociologi i kritiksociologien. Vi står med det, jeg vil kalde en "kritisk kritiksociologi". Det viser sig på følgende måder:

For det første vil B\&C bidrage til "relancering" af kapitalismekritikken efter afvæbningen af den sociale kritik gennem forskydning og den delvise integration af den kunstneriske kritik, som ifølge B\&C har fundet sted siden de sene 1970ere. Kritiksociologien deltager selv i det kritiske samfund og er som sådan kritisk sociologi. I god overensstemmelse med dette "deltagerperspektiv" (Nielsen 2007: 238) på kritikken fremlægges forslag til en aktualiseret social og kunstnerisk kritik af netværkskapitalismen og projektregimet. Socialt drejer det sig primært om at modarbejde de mobiles udbytning af de immobile, op- 
rette sociale værn mod fleksibilitetens mangfoldige usikkerheder og sikre lige muligheder (B\&C 1999: 471-500). Kunstnerisk gælder det for det første om at adskille frigørelse og mobilitet; man kan ikke længere "knytte frigørelse sammen med [...] mobilitet [...] i en tid, hvor mobilitetskravet er et af kapitalismens yndlingsord“ (Blondeau \& Sevin 2008: 61). For det andet gælder det om at modarbejde den gennemgribende varegørelse af mennesker, som gemmer sig i projektregimets manglende sondring mellem arbejde og ikke-arbejde (B\&C 1999: 568-576).

Men kritiksociologien er også kritisk sociologi i mere fundamental forstand. Som sociologisk teori indtager den selv et kritisk standpunkt. Selve den pragmatiske vending er kritisk - den tager hos B\&C form af det, jeg vil kalde pragmatisk kritik. Den pragmatiske sociologi går "imod fatalismerne" (ibid.: 631), der ser kapitalismens forandringer de sidste 30 år som udtryk for uundgåelige mutationer, systemiske restriktioner (ibid.: 28), overordnede globaliseringsdynamikker, "kræfter, der eksisterer hinsides menneskers vilkår" (B\&C 2002: 20). Den kritiske pragmatisme beskriver tværtimod kapitalismens historie som handlingernes historie. Den viser, hvordan "menneskene skaber deres historie", hvordan tingene er blevet afgjort og kunne have taget andre retninger. Dette lægger op til, at der fortsat kan handles anderledes. Hvis kapitalismen har kunnet forandre sig ved forskydninger, så kan den også forskydes i retning af større retfærdighed og et mere autentisk liv (B\&C 1999: 29-30, 638). Således er "historien forbundet med kritikken" (ibid.: 30).

Den pragmatiske kritik har altså sin kritiske dimension fra det forhold, at den står i opposition til den kritiktype, som refererer til skjulte kræfter, strukturer, systemiske sammenhænge eller lovmæssigheder. B\&C har dog også en rem af huden af denne stærkere kritiktype. Man kan her pege på det indre forhold mellem kapitalismebegreb og kapitalismekritik, som begrundes i et teoretisk argument om kapitalismens beskaffenhed. Også påstanden om, at kritikken driver forandringerne i kapitalismens ånd, og at kapitalismen "behøver sine fjender", synes at hvile på teoretiske forudsætninger, som overskrider den kritiske pragmatismes rækkevidde. Endelig forekommer udbytningsteorien at overskride en kritisk pragmatismes rammer. Teorien forudsætter påvisning af, at de immobiles "immobilitet er nødvendig for de andres mobilitet", hvilket igen forudsætter konstruktionen af et netværks- og socialkapitalteoretisk argument, som forekommer at høre hjemme i et andet register end pragmatikkens (ibid.:446-448). Det gør selve retfærdiggørelsesargumentet for, hvad udbytning er, når forudsætningen er opfyldt, derimod ikke, hvilket kan tydeliggøres ved et kort blik på den nye kritiske teori.

\section{Retfærdiggørelse, anerkendelse og den nye kritiske teori}

Axel Honneths bygger sin anerkendelsesteoretiske fornyelse af den kritiske teori på, at kritik ikke kan begrundes i en venstrehegeliansk idé om fremskridt i den samfundsmæssig fornuft, heller ikke hvis den tager form af kommunika- 
tiv fornuft (Honneth 2007: 65-66). Den kritiske teoris normative grundlag skal derimod findes i anerkendelsen, som er "den normative forudsætning for al kommunikativ handlen" (Honneth 2005: 37). Honneth skelner her mellem tre former for social anerkendelse: anerkendelsen i intimsfæren, som springer af kærlighedens og venskabets følelsesmæssige kontakt, anerkendelsen i den retslige sfære som "moralsk tilregneligt medlem af et samfund" og anerkendelsen i socialsfæren af individuelle præstationer og evner (ibid.: 43). Af disse anerkendelsesformer flyder henholdsvis selvtilliden, selvagtelsen og selvværdsættelsen (Willig 2005: 14).

Som Laurent Thénevot via Paul Ricœur (Ricœur 2005: 293-331) har bemærket, er der store ligheder mellem denne opdeling af anerkendelsens former og den pragmatiske sociologis sondring mellem forskellige pragmatiske regimer (Thévenot 2007a: 127). Ved et møde i Frankfurt i 2006 har Axel Honneth da også understreget de to grupperingers fælles "modstand mod den eksterne kritik, som den fastholdes af en vis kritisk sociologi" og den fælles "opmærksomhed over for en kritik, som er forankret i samfundet" (ibid.: 141). Mere præcist springer det i øjnene, at regimemodellen dækker såvel selvagtelsen som selvværdsættelsen: selvagtelsen gennem kravet om fælles humanitet og værdighed og selvværdsættelsen gennem det overordnede princip i et eller flere regimer. Også begrebet om stærk udbytning har klar affinitet til den nye kritiske teori, idet den stærke udbytning netop rammer selve den menneskelige værdighed, dvs. både selvagtelsen og selvværdsættelsen.

En kritisk teori, som vil basere sit kritiske standpunkt, ikke på en egen indsigt $\mathrm{i}$ en samfundsmæssig fornuft, men på foreliggende uretfærdighedsfølelser i samfundet, kan således også trække på den pragmatiske kritiksociologi. Og denne kritiksociologi kan profilere "sine kritiske ængstelser og bekymringer om undertrykkelse" som kritisk teori ved at fokusere på systematiske sammenhænge mellem lav eller manglende anerkendelse i flere verdener (Thévenot 2007a: 140).

\section{Pragmatisk og stærk kritik}

I lighed med Max Weber var Karl Marx af den opfattelse, at det moderne kapitalistiske system kan reproducere sig ved egne kræfter. Til forskel fra Weber er det hos Marx ikke kun de økonomiske relationers utilitaristiske tvang, der sikrer reproduktionen, men også bevidsthedsformerne, vare-, penge-, løn-, og kapitalfetishismen, som systemet selv frembringer (Lundkvist 1973). Hos Marx genereres kapitalismens ideologi, dens "ånd", altså af det kapitalistiske økonomiske system selv, mens den hos Weber skal findes uden for systemet. Modsat Weber kan Marx derfor hævde at levere en "fremstilling af systemet og gennem fremstillingen kritik af dette" (Marx 1963: 550). Denne kritik grunder sig på en i fremstillingen indbygget transcendens, nemlig pengenes og kapitalens grund i det abstrakte (mer)arbejde. Marx lægger i Kapitalen ud med at hævde eksistensen af en vareverden, som kendetegnes af konsistente, ækviva- 
lente bytterelationer mellem alle varer. Dette forudsætter, at der findes penge, en fælles almen ækvivalent, som alle varer måler sig i forhold til. Denne immanente sammenhæng mellem vareækvivalens (værdi) og penge finder Marx det imidlertid nødvendigt at begrunde i et fælles tredje, som ikke forefindes på immanensplanet, nemlig det abstrakte menneskelige arbejde (Marx 1972: 5152, Albertsen 1981: 23-26, 177). Denne transcendente grund danner herefter udgangspunkt for såvel påvisning af nødvendige fremtrædelses- og cirkulationsformer som kritikken af deres fordrejningsmekanismer.

Denne stærke kritikmodel, hvor kritikkens transcendente grund fremskaffes teoretisk, genfindes i lacaniansk-marxistisk udgave hos Slavoj Žižek. Her tager transcendensen, der "ligger bag", form af en mangel af absolut, ontologisk karakter (Larsen 2000: 144). Manglen virker som "det tredje subjekt", der hverken er fuldstændig domineret af samfundsmæssige strukturer eller frit, autonomt og ansvarligt. Det tredje subjekt er derimod den "rest", som til enhver tid og ethvert sted er hverken det ene eller det andet. Dette "subjekt af det ubevidste" søger på den ene side at tildække den "konstitutive værensmangel" ved en altid ufuldstændig identifikation med ideologi; på den anden side indebærer subjektets uregerlighed også altid muligheden for radikalt brud med den givne orden (Bjerre \& Laustsen 2006: 18-25, 79-81).

Stærk kritik i Marx's og Žižeks i eks forstand er ikke tilgængelig for B\&C. Dertil er deres kapitalismeforståelse for weberiansk, og de har ikke tilgang til psykoanalytisk viden om subjektet af det ubevidste, som kan forklare, hvordan og hvorfor kapitalismens ånd virker som ideologi. Den pragmatiske sociologis subjekter er ræsonnable individer, der kan udtrykke, hvorfor de føler sig uretfærdigt behandlet og fortælle, hvorfor de tilslutter sig en ideologi.

\section{Kritisk distance og kritisk nærhed: ANT og kritisk pragmatisme}

Hos Bruno Latour tager den pragmatiske vending form af et opgør med enhver sociologi, som på forhånd mener at besidde en sådan indsigt i det sociales grundlæggende egenskaber og lovmæssigheder, at den kan forklare sociale fænomener. Over for denne "sociologi om det sociale" hævdes, at det sociale ikke foreligger som forklaringsfaktor. Det skal tværtimod selv forklares. Menneskene deler det sociale med tingene på mangfoldige måder, og det er derfor altid på forhånd uafklaret, hvori det sociale består. Det gælder om at følge de humane og ikke-humane aktører i deres sammenviklinger, om at udrede og udfolde, hvordan de er associerede med hinanden og får hinanden til at agere. Forklaring vil sige netop denne redegørende udfoldelse af aktørernes indbyrdes associationer - ikke af andet og ikke mere (Latour 2005: 8, 14-15, 40, 46-50).

Er Latour således afvisende over for "det sociales sociologi", så er han det i endnu højere grad over for den kritiske sociologi. Den gør ikke alene brug af det sociale som forklaringsfaktor, men vil ydermere forklare, hvorfor de sociale aktører nødvendigvis må miskende sociale forklaringer. Denne opera- 
tion indebærer, at aktørernes benægtelse af de sociale forklaringer kommer til at gælde som deres videnskabelige bekræftelse. Inddrager kritisk sociologi ikke-humane aktører, da reduceres de til feticher, hvis ageren de menneskelige aktører tror på. Fetichismen skyldes dog menneskene selv og de sociale forhold, de determineres af. Med sådanne forklaringsstrukturer vil kritisk sociologi, ifølge Latour, altid få ret (2004: 234-240; 2005: 9, 137, 249, 251).

Kritisk sociologi er således noget af det værste, der kan vederfares associerede mennesker og ting. Den er ikke empirisk. Den er "vampyrisk" (Latour 2005: 50)! Ikke desto mindre har også ANT en kritisk dimension. Kritik består ikke i at afsløre skjulte kræfter bag givne tilstande for at fremme politisk handling. Dette forhindrer politisk handling, da sociale forklaringer ifølge Latour har det med at erstatte politik (ibid.: 250). Det gælder derimod om at finde måder, hvorpå man kan "registrere nye associationer og undersøge, hvordan man kan samle dem i en tilfredsstillende form" (Latour 2005: 261). Det kræver kritisk nærhed, - ikke afsløringens kritiske distance (Latour 2005: 253).

Hvordan tager NEC sig ud i dette lys? Den ligner, vil jeg mene, i høj grad en sociologi, som med forudfattede kategorier lukker af for, hvilke entiteter der tæller med i associationerne af mennesker og ting. Latour er således skeptisk over for et enhedsbegreb om kapitalismen, netop fordi det fungerer som et allerede foreliggende socialt forklaringsbegreb (ibid.: 178, 137, 252). "Lad være med at fokusere på kapitalismen, [...] følg forbindelserne, "følg aktørerne selv“"“(ibid.: 179). På tilsvarende vis har Michel Callon eksplicit udtrykt uenighed med Boltanski. Kapitalisme er ikke et homogent og amoralsk akkumulationssystem, men forefindes i forskellige former og med forskellige markeder, hvor der konstant forhandles etiske og politiske spørgsmål. Netop opretholdelsen af et homogent kapitalismebegreb er med til at opretholde forestillingen om, at de sociale aktører ikke kan ændre organiseringen af økonomiske aktiviteter. Der er kun to alternativer: ødelæggelse eller accept (Barry \& Slater 2002: 298).

B\&C ville her protestere: netop den pragmatiske tilgang viser, hvordan aktørerne skaber historien. Callons pointe er imidlertid, at den kapitalismekritik, som opererer med et enhedsbegreb om kapitalisme, netop derved også kommer til at styrke dette begreb, hvilket B\&Cs analyse på paradoksal vis viser. Kapitalismens antikapitalistiske fjender opretholder forestillingen om, at den findes i ental! (ibid.: 297-298). En kapitalismekritik, som bygger på kritisk nærhed, ville derimod begynde med at lægge troen på kapitalismen i ental bort (Callon \& Latour 1997: 67).

Fra et ANT-perspektiv mangler den kritiske pragmatisme således kritisk nærhed, hvilket kan tilbageføres til lige netop det anstrøg af stærk kritik, som kan spores hos Boltanski og Chiapello. Dette anstrøg er dog, vil jeg mene, svagt. Det har ikke stærk kritik i Marxs og Žižeks forstand som grundlag. Det er snarere, med Latours sondring, det sociales sociologi end kritisk sociologi, der virker hos $\mathrm{B} \& \mathrm{C}$. 


\section{Konkluderede bemærkninger}

Med afvisningen af at besidde privilegeret indsigt $\mathrm{i}$ transcendente, bagvedliggende kræfter og forhold, som kan danne grundlag for ideologiforståelse, samfundsteori og kritikbegreb, bidrager B\&C til den "sekularisering" af kritisk teori, som søger kritikkens basis i social praksis og erfaringsdannelse (Nielsen 2001: 24-32). Kritiksociologien viser, hvordan retfærdiggørelse og kritik udfolder sig som plural social praksis i moderne samfund. Fra et ANT-synspunkt kan regimerne forekomme lige lovligt a-priorisk "kantianske", men det kan dog ikke skjule, at det også for Latour giver god mening kritiksociologisk at følge og udfolde de aktør-netværk, hvorigennem aktørerne "stiger op i generalitet" (Latour 2005: 232, 23).

Men B\&C vil ikke blot levere nyttig kritiksociologi for andres kritiske sociologi. De vil selv praktisere den. Til trods for, at denne ambition er uden stærkt kritisk grundlag, så distancerer de sig her fra ANT. B\&Cs svage kritiske sociologi hviler på et overgribende og homogeniserende kapitalismebegreb og en udbytningsteori, som ANT ikke ville betjene sig af. Til gengæld har B\&Cs kritiske sociologi, ikke mindst gennem udbytningsteorien, tydelig affinitet til Axel Honneths anerkendelsesteoretiske nyformulering af kritisk teori.

B\&Cs kritiske kritiksociologi udmærker sig ved at kunne forbinde legitimitet og legitimering, retfærdiggørelse, kritik og styrke, "størrelsesforhold" og "styrkeforhold" uden at forudsætte stærk kritik. "Afsløringen" af magt og styrke "bag" legitimiteten forbinder ganske vist transcendens og immanens, men magten er ikke en forklaringsinstans, der ligger "dybere" end legitimiteten. Magten er ikke det transcendent bagvedliggende, som styrer immanensen, men selve immanensen, som kan måles på retfærdiggørelsesprincipper, hvis transcendens har generaliserende karakter, ikke dybdekarakter.

Forholdet mellem kritiksociologi og kritisk sociologi hos B\&C kan herefter karakteriseres således: Kritiksociologien bereder og kvalificerer grundlaget for den kritiske kritiksociologi ved at undersøge kritik som social praksis. På baggrund heraf kan sociologien stille sig selv den opgave at deltage i det kritiske samfund, støtte bestemte social kritikker og selv forholde sig pragmatisk kritisk.

Kritiksociologiens renoncering på et eget kritisk standpunkt har således alene været en provisorisk foranstaltning for at berede grundlaget for at bedrive kritisk sociologi på et mere solidt grundlag end stærk kritik (B\&C 2005: xi, Boltanski 2007). Set i dette lys er NEC et forsøg fra Boltanskis side på at balancere arven fra Bourdieu, dvs. forståelsen af det sociale i termer af magt og dominans, med interessen for retfærdighed (Moulier-Boutang 2000: 130). Luc Boltanski understreger selv i 2006, at hans arbejde de sidste 20 år har været præget af "et ønske om ikke at forkaste det, jeg tidligere har lært". Omvæltningen i 1980erne var "hverken en intellektuel fornægtelse eller en ændring i politisk orientering" (Boltanski et al. 2006: 53). 


\section{Noter}

1. Dette og det følgende afsnit trækker på Albertsen 2002: 50-55.

2. Det grønne regime og projektregimet har endnu ingen grammatikere. Det grønne regime konstrueres ud fra forskelligt teoretisk og empirisk materiale, projektregimet ved sammenligning af managementlitteratur fra 1960'erne og 1990'erne (B\&C 1999: 93-102). Jeg har i Albertsen (2005) fremlagt en argumentation for, at Spinoza kunne være projektregimets grammatiker. Det kunne måske også gælde det grønne regime. Spinoza er en vigtig kilde til den såkaldt dybe økologi.

3. Se Jagd (1998: 43) for et særdeles fyldigt skema og B\&T (1999: 368) for et mindre fyldigt.

\section{Litteratur}

Albertsen, Niels (1981): Værdi, penge og kommensurabilitetsargument. Specialeafhandling. Aarhus Universitet: Institut for Statskundskab.

Albertsen, Niels (2002): "Retfærdiggørelse i byen". Distinktion, (4): 45-61.

Albertsen, Niels (2005): "From Calvin to Spinoza. The New Spirit of Capitalism". Distinktion, (11): 71-86.

Barry, Andrew \& Don Slater (2002): “Technology, politics and the market: an interview with Michel Callon". Economy and Society, 31 (2): 285-306.

Bénatouil, Thomas (1999): "A Tale of Two Sociologies. The Critical and the Pragmatic Stance in Contemporary French Sociology“. European Journal of Social Theory, 2 (3): 379-396.

Bidet, Jacques (2002): “L'esprit du capitalisme. Questions à Luc Boltanski et Ève Chiapello", s. 215-233 i Jean Lojkine (red.): Les Sociologies critiques de capitalisme. Paris: Presses Universitaires de France.

Bjerre, Henrik Jøker \& Carsten Bagge Laustsen (2006): Slavoj Žižek. Frederiksberg: Roskilde Universitetsforlag.

Blondeau, Cécile \& Jean-Christophe Sevin (2008): “En sociologi der hele tiden sættes på prøve. Interview med Luc Boltanski". Dansk Sociologi 19 (2): 39-63.

Boltanski, Luc (1990): L'Amour et la justice comme competences. Trois essais de sociologie de l'action. Paris: Editions Métailié.

Boltanski, Luc (2002): "The left after May 1968 and the longing for total revolution". Thesis Eleven, 69 (1): 1-20.

Boltanski, Luc (2004): La Condition fotale. Une sociologie de l'engendrement et de l'avortement. Paris: Gallimard.

Boltanski, Luc (2006): "Les Changements actuels du capitalisme et la culture du

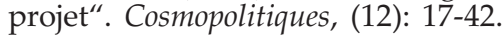

Boltanski, Luc (2007): “Bruno Latour et la critique“. Forelæsning d. 24. Juni 2007 til symposiet Exercises de métaphysique empirique (Autour des travaux de Bruno Latour), Centre Culturel International de Cerisy-la-Salle, F-50210 Cerisy-la-Salle 23.-30. juni 2007.

Boltanski, Luc (2008): "Kritiske handlinger, krav om retfærdiggørelse og bearbejdning af sociale modsætninger" Dansk Sociologi 19 (2): 13-37.

Boltanski, Luc \& Ève Chiapello (1999): Le Nouvel Esprit du capitalisme. Paris: Gallimard.

Boltanski, Luc \& Ève Chiapello (2002): The New Spirit of Capitalism. Paper to be presented to the Conference of Europeanists, March 14-16, 2002, Chicago. http:/ /www. sociologia.unimib.it/mastersqs/rivi/boltan.pdf (konsulteret 20/08/04). 
Boltanski, Luc \& Ève Chiapello (2005): "Preface to the English Edition", s. ix-xxvii i Luc Boltanski \& Ève Chiapello: The New Spirit of Capitalism. London: Verso.

Boltanski, Luc \& Laurent Thévenot (1991): De la justification. Paris: Gallimard.

Boltanski, Luc \& Laurent Thévenot (1999): "The Sociology of Critical Capacity". European Journal of Social Theory, 2 (3): 359-377.

Boltanski, Luc \& Laurent Thévenot (2000): “The Reality of Moral Expectations. A Sociology of Situated Judgement". Philosophical Explorations, 3 (3): 208-231.

Boltanski, Luc et al. (2006): "L'effet Ricoeur dans les sciences humaines" Esprit, (323): 43-67.

Callon, Michel \& Bruno Latour (1997): “Tu ne calculeras pas!“ ou comment symétriser le don et le capital“. Revue du MAUSS semestrielle, (9): 45-70.

Chiapello, Ève (2003): "Reconciling the Two Principal Meanings of the Notion of Ideology: The Example of the Concept of the 'Spirit of Capitalism'“. European Journal of Social Theory, 6 (2): 155-171.

Corcuff, Philippe (2004): “Néocapitalisme et individualisme: en partant du Nouvel Esprit du capitalisme et d'Empire". Contretemps, (11): 117-129.

Hardt, Michael \& Antonio Negri (2000): Empire. Cambridge, Massachusetts: Harvard University Press.

Hardt, Michael \& Antonio Negri (2004): Multitude: War and Democracy in the Age of Empire. New York: The Penguin Press.

Honneth, Axel (2005): Behovet for anerkendelse. København: Hans Reitzels Forlag.

Honneth, Axel (2007): Pathologien der Vernunft. Geschichte und Gegenwart der Kritischen Theorie. Frankfurt a. M.: Suhrkamp Verlag.

Jagd, Søren (1998): “Økonomi, usikkerhed og koordinering - en introduktion til konventionsteorien". Dansk Sociologi, 9 (3): 37-54.

Karsenti, Bruno (2000): “Le capitalisme au présent. Une lecture du "Nouvel Esprit du capitalisme" de L. Boltanski et E. Chiapello". Multitudes, (3): 143-160.

Lafaye, Claudette \& Laurent Thévenot (1993): “Une Justification écologique? Conflits dans l'aménagement de la nature". Revue Française de Sociologie, 34 (4): 495-524.

Larsen, Lars Bo (2000): “Hvad ligger der bag? Intet? Slet intet?". Distinktion, (1): 141144.

Latour, Bruno (1984): “Irréductions", s. 169-265 i Bruno Latour: Les Microbes, guerre et paix, suivi de Irréductions. Paris: Éditions A. M. Métailié.

Latour, Bruno (1996): “On Interobjectivity" Mind, Culture \& Activity, 3 (4): 228-245.

Latour, Bruno (2004): “Why has Critique Run Out of Steam? From Matters of Fact to Matters of Concern". Critical Inquiry, 30 (2): 225-248.

Latour, Bruno (2005): Reassembling the Social. An Introduction to Actor-Network-Theory. Oxford: Oxford University Press.

Luhmann, Niklas (2000): “"Hvad er tilfældet?" og "Hvad ligger der bag?" De to sociologier og samfundsteorien". Distinktion, (1): 9-25.

Lundkvist, Anders (1973): Kapitalens Bevidsthedsformer. Århus: Modtryk.

Marx, Karl (1963) [1858]: “Marx an Lassalle, 22. Februar 1858“ i Marx/Engels: Werke Bd. 29, Berlin: Dietz Verlag.

Marx, Karl (1972) [1873]: Das Kapital. Erster Band. Berlin: Dietz Verlag. 
Marx, Karl (1974) [1857-58]: Grundrisse der Kritik der Politischen Ökonomie. Berlin: Dietz Verlag.

Marx, Karl \& Friedrich Engels (1971) [1848]: "Det kommunistiske partis manifest", s. 19-59 i Karl Marx \& Friedrich Engels Udvalgte Skrifter I. København: Forlaget Tiden.

Moulier-Boutang, Yann (2000): “Vers un renouveau de la critique sociale". Multitudes, (3): 129-142.

Nielsen, Henrik Kaare (2001): Kritisk teori og samtidsanalyse. Århus: Aarhus Universitetsforlag.

Nielsen, Henrik Kaare (2007): Konsument eller samfundsborger? Kritiske essays. Århus: Klim.

Ricœur, Paul (2005): Parcours de la reconnaissance. Paris: Gallimard.

Thévenot, Laurent (2006): L'action au pluriel. Sociologie des régimes d'engagement. Paris: Éditions La Découverte.

Thévenot, Laurent (2007a): "Reconnaissances avec Paul Ricœur et Axel Honneth", s. 127-143 i Christian Delacroix \& François Dosse \& Patrick Garcia: Paul Ricour et les sciences humaines. Paris: Éditions La Découverte.

Thévenot, Laurent (2007b): “The Plurality of Cognitive Formats and Engagements: Moving between the Familiar and the Public". European Journal of Social Theory, 10 (3): 409-423.

Weber, Max (1972): Den protestantiske etik og kapitalismens ånd. København: Fremad.

Willig, Rasmus (2005): “Indledning“, s. 7-23 i Axel Honneth: Behovet for anerkendelse. København: Hans Reitzels Forlag. 